\title{
Pengaruh Gaya Kepemimpinan, Budaya Organisasi dan Kompetensi Terhadap Kinerja Guru Di SMA Negeri 13 Palembang
}

\author{
Yuniarti
}

Published online: 5 December 2021

\begin{abstract}
Absract
This study aimed to determine the influence Leadership Style, Organisational Culture and Competence of Teacher Performance at Senior High School number 13 Palembang. This Research was done during 3 (three) months included design, executing and report the result. The experiment was conducted at Senior High School number 13 Palembang. In this study population was 70 people consisting of 30 people as sample test and 40 people as sample. Sampling in this study using census sampling technique that is sampling from a population as a whole. From dataprocessing result known that regression coefficient for variable of Leadership Style $\left(\mathrm{X}_{1}\right)$ equal to 0,304 with significant level equal to 5\%, regression coefficient for variable of Organisational Culture $\left(\mathrm{X}_{2}\right)$ equal to 0,269 with significant level equal to $5 \%$, regression coefficient for variable of Competence $\left(\mathrm{X}_{3}\right)$ equal to 0,422 with significant level equal to $5 \%$. From the research result known that correlatoin coefficient for variable of Leadership Style $\left(\mathrm{X}_{1}\right)$ with Teacher Performance (Y) equal to 0,304 with significant level equal to $5 \%$, correlation coefficient for variable of Organisational Culture $\left(\mathrm{X}_{2}\right)$ equal to 0,269 with significant level to $5 \%$. Correlation coefficient for variable Competence $\left(\mathrm{X}_{3}\right)$ equal to 0,422 with significant level equal to $5 \%$, while value of correlation coefficient $(\mathrm{R})$ equal to 0,626 or $62,6 \%$ meaning to have very strong relation between independent variable and dependent variable, also known that determination coefficient $\left(R^{2}\right)$ equal to 0,757 This value can be interpreted that level of influence percentage among variable of Leadership Style, Organisational Culture and Competence together to Teacher Performance is 75,70\%. Equally the effective contribution of Leadership Style, Organisational Culture and Competence with Teacher Performance at Senior High School number 13 Palembang is equal to 75,70\% while the rest $24,60 \%$ influenced by other variable which is not packed into this research. The implementation of this research is to suggest the Manager at Senior High School number 13 Palembang to improve continously Leadership Style, Organisational Culture and Competence, so that wittingly themselves together always try to utilize to reach the target which have been specified (Teacher Performance).
\end{abstract}

Keywords: Leadership, Organisational, Competence, Teacher Performance

\section{PENDAHULUAN}

Kebijakan pembangunan nasional meletakkan peningkatan mutu sumber daya manusia sebagai prioritas utama. Pendidikan merupakan aspek penting untuk meningkatkan kualitas sumberdaya manusia agar mampu bersaing seiring perkembangan zaman. Keberadaan suatu bangsa dapat diukur dengan tinggi rendahnya tingkat perkembangan pendidikan di 215 bsolu tersebut. Menurut Undang-Undang Nomor 20 Tahun 2003 tentang Sistem Pendidikan Nasional, yang dimaksud pendidikan adalah usaha sadar dan terencana untuk mewujudkan suasana

\footnotetext{
*) corresponding author

Yuniarti

STIA Bala Putra Dewa

Jl. Urip Sumoharjo, 2 Ilir, Kec. Ilir Tim. II, Kota Palembang, Sumatera Selatan 30163
}

Email: ibrahimyuniarti658@gmail.com dan proses pembelajaran agar peserta didik secara aktif mengembangkan potensi dirinya untuk memiliki kekuatan spiritual keagamaan, pendidikan diri, kepribadian, kecerdasan, akhlak mulia, serta keterampilan yang diperlukan dirinya, masyarakat, bangsa dan negara.

Untuk mencapai hasil pendidikan yang baik, harus melalui proses pendidikan yang baik dan terarah. Pendidikan yang baik dan terarah, hanya mungkin dapat dilaksanakan oleh guru yang professional. Sebagai tenaga, guru memegang peranan dan tanggung jawab yang sangat penting dalam pelaksanaan program pengajaran di sekolah. Menurut Depdikbud (2015:3). Guru merupakan salah satu komponen esensial dalam suatu 215 bsolu pendidikan. Peran, tugas, dan tanggungjawab guru sangat bermakna dalam mewujudkan tujuan pendidikan nasional, yaitu mencerdaskan kehidupan bangsa, meningkatkan kualitas manusia Indonesia, meliputi kualitas iman dan takwa, akhlak mulia, dan penguasaan ilmu pengetahuan, teknologi, dan seni, serta mewujudkan masyarakat Indonesia yang maju, adil, makmur, dan beradab. 
Peningkatan kinerja guru ini dipengaruhi beberapa hal seperti gaya kepemimpinan yang baik, budaya organisasi dan kompetensi guru untuk mendukung peningkatan kinerja guru.

Penilaian kinerja guru dilakukan untuk dapat mencapai sasaran dan dalam mematuhi standar yang telah ditetapkan sebelumnya, agar membuahkan tindakan dan hasil yang diinginkan. Penilaian kinerja dilakukan untuk menekan prilaku yang tidak semestinya dan untuk merangsang serta menegakkan prilaku yang semestinya diinginkan melalui umpan balik hasil kinerja pada waktunya dengan suatu penghargaan.

Keberhasilan seorang pemimpin dalam menggerakan bawahannya dalam melaksanakan visi dan misi organisasi akan dipengaruhi oleh gaya kepemimpinan dan budaya organisasi yang merupakan proses atau cara pemimpin menggunakan hubungan dan wewenangnya terhadap yang dipimpin. Kegiatan pokok kepemimpinan adalah melakukan pembinaan karyawan pada umumnya dan guru pada khususnya agar kualitas pembelajarannya meningkat.

Budaya organisasi di sekolah harus mampu mengakomodasi perubahan-perubahan baik terhadap guru. Budaya organisasi sekolah juga memiliki visi dan misi yang mengakibatkan orang-orang yang ada di dalam organisasi tersebut proaktif, antisipatif khususnya pada era informasi sekarang ini yang penuh tantangan, peluang, dan persaingan.

Salah satu aspek penting untuk mewujudkan pendidikan yang mampu menghasilkan sumberdaya manusia yang berkualitas yaitu guru. Guru pada dasarnya merupakan salah satu komponen dalam proses pembelajaran yang ikut berperan dalam usaha pembentukan sumberdaya manusia yang potensial dalam bidang pembangunan. Sebagai komponen dalam bidang kependidikan, seorang guru harus berperan serta secara aktif dan menempatkan kedudukannya sebagai tenaga absolute.

\section{Tinjauan Pustaka}

Menurut Mangkunegara, (2010:67) isitilah kinerja berasal dari kata "Job Performance" atau "Actual Performance" yang artinya prestasi kerja atau prestasi sesungguhnya yang dapat dicapai oleh seseorang. Lebih lanjut Mangkunegara (2010), dalam penjelasannya menguraikan pengertian kinerja sebagai hasil kerja secara kuantitas yang dicapai oleh seorang pegawai dalam melaksanakan tugasnya sesuai dengan tanggung jawab yang diberikan kepadanya. Kinerja adalah hasil pelaksanaan suatu pekerjaan baik bersifat fisik/material maupun non fisik/non material karena dipengaruhi 54bsolu kemampuan (ability) dan 54bsolu disiplin kerja (motivation). Berdasarkan pendapat tersebut, kinerja dapat diartikan sebagai proses pelaksanaan kerja dan dapat dilihat secara nyata dari hasil kerja yang telah dicapai.

Pemimpin adalah orang yang mempunyai tugas untuk mengarahkan dan membimbing bawahan dan mampu memperoleh dukungan dari bawahannya sehingga dapat menggerakkan mereka kearah pencapaian tujuan organisasi. Kepemimpinan merupakan proses mempengaruhi kegiatan kelompok yang terorganisir dalam usaha menentukan tujuan dan pencapaiannya.

Menurut pendapat Gatto (2012) yang dikutip oleh Imam (2012:45) menyatakan bahwa ada 4 gaya kepemimpinan yaitu; gaya kepemimpinan direktif, gaya kepemimpinan konsultatif, gaya kepemimpinan partisipasi dan gaya kepemimpinan delegasi. Dapat disimpulkan bahwa gaya kepemimpinan adalah merupakan bidang pekerjaan yang dilandasi pendidikan, pengetahuan, kemampuan, ketrampilan dan keahlian tertentu sehingga mempunyai kompetensi. Pada penelitian ini penulis menggunakan pendekatan teori Gatto (2012).

Menurut Deal dan Kennedy yang dikutip oleh Ndraha (2015:8) mengatakan bahwa budaya pada hakekatnya merupakan pola yang terintegrasi dari perilaku manusia yang mencakup pikiran, ucapan, tindakan, artifak-artifak dan bergantung pada kapasitas manusia untuk belajar dan mentransmisikannya bagi keberhasilan generasi yang ada. Dari pengertian ini dapat dipahami bahwa budaya organisasi tidak bisa begitu saja ditangkap dan dilihat oleh orang luar, namun dapat dipahami dan dirasakan melalui perilaku-perilaku anggotanya serta nilai-nilai yang mereka anut. Deal dan Kennedy menambahkan, nilai pada hakekatnya merupakan inti dari suatu budaya. Ia merupakan esensi dari philosophi organisasi. Nilai memberikan suatu sense of common direction bagi semua anggotanya dan petunjuk bagi perilaku sehari-harinya. Semakin kuat nilai-nilai itu diinternalisasi, maka semakin kuat pula budaya mempengaruhi kehidupan mereka. Terkadang budaya itu sedemikian kuat dan kohesif, sehingga setiap orang tahu tujuan organisasi dan mereka mau bekerja untuk mencapainya. Menurut Ndraha (2005:80) budaya adalah sebuah proses (throughput). Sebuah proses perubahan dari kondisi yang satu (input) ke kondisi selanjutnya (output) atau sebuah proses pengubahan seperangkat input menjadi output yang sesuai dengan visi dan misi atau tujuan organisasi. Dari pemakaian, penikmatan atau pelaksanaan output diperoleh outcome, dari evaluasi outcome diperoleh bahan untuk dijadikan feedback (reinput), demikian seterusnya.

Pelaksanaaan sertifikasi guru ini, merupakan salah satu wujud implementasi Undang-Undang Nomor 14 Tahun 2005 tentang Guru dan Dosen, melalui standar kompetensi dan sertifikasi guru sebagai proses pemberdayaan, diharapkan ada perbaikan tata kehidupan yang lebih adil, demokratis, serta tegaknya kebenaran dan keadilan dikalangan guru dan tenaga kependidikan. Dalam standar kompetensi dan seritfikasi guru, pemberdayaan dimaksudkan untuk memperbaiki kinerja sekolah melalui kinerja guru agar dapat mencapai tujuan secara optimal, efektif, dan efisien.

\section{METODE PENELITIAN}

Penelitian ini dilaksanakan di SMA Negeri 13 Palembang yang beralamat di Jln. Adi Sucipto No. 2803 Bandara SMB II Palembang. Penelitian ini diharapkan dapat memberikan andil dan manfaat dalam peningkatan gaya kepemimpinan, budaya organisasi, kompetensi dan kinerja. Dalam pengumpulan data, peneliti menggunakan teknik wawancara, dokumentasi, dan penyebaran kuisioner kepada seluruh responden, pengolahan data dan penulisan penelitian dinyatakan selesai serta dapat diseminarkan dan diuji. Waktu yang diperlukan untuk penelitian ini selama 3 (tiga) bulan, yaitu dari bulan Juli sampai dengan bulan September 2019, sejak proses perencanaan, pelaksanaan dan pelaporan hasil penelitian, agar penelitian dapat dilaksanakan secara sistimatis dan berkesinambungan.

Metode yang dipergunakan yaitu metode survey kuantitatif dengan pendekatan deskriftif. Dalam hubungannya dengan teknik survey ini, Haryono (2010:62) lebih lanjut menyatakan survey adalah sebuah teknik penelitian dimana informasi dikumpulkan penggunaan kuisioner. Pendekatan deskriptif dipandang paling tepat untuk melaksanakan penelitian ini dengan pertimbangan bahwa informasi yang diharapkan diperoleh yakni tentang 
gejala pada saat penelitian dilakukan. Analisis sebab akibat diperlukan untuk menyelidiki pengaruh 55 bsolute bebas dengan 55bsolute terikat sehingga hipotesis dapat teruji secara 55 bsolut dan melalui analisis 55 bsolute 55 yang akurat.

Populasi dan wilayah generalisasi yang terdiri atas obyek/subyek yang mempunyai kuantitas dan karakteristik tertentu yang ditetapkan oleh peneliti untuk dipelajari dan kemudian ditarik kesimpulannya. Populasi dalam penelitian ini adalah Guru SMA Negeri 13 Palembang sedangkan sampel adalah bagian dari populasi yang akan dijadikan objek penelitian. Dalam penelitian ini jumlah populasi adalah 59 orang. Pengambilan sampel dalam penelitian ini menggunakan sampel jenuh yaitu pengambilan sampel dilakukan secara keseluruhan dari jumlah populasi. Dalam melaksanakan penelitian ini peneliti memerlukan pengumpulan data melalui survey data yang diperoleh langsung dari sumber data dengan metode pengumpulan data yang dilakukan dengan cara pemberian / penyebaran kuisioner tentang keempat 55bsolute penelitian.

Menurut Siswoyo (2014:149) apabila sama sekali tidak ada pengetahuan tentang besarnya variance dari populasi. Dalam hal seperti ini cara terbaik adalah cukup dengan mengambil persentase tertentu, katakanlah 5\%, 10\% atau $50 \%$ dari seluruh populasi. Beberapa hal yang dapat dipakai sebagai petunjuk untuk menentukan besarnya persentase sampel yaitu:

- Bila populasi $\mathrm{N}$ besar, persentase yang kecil saja sudah dapat memenuhi syarat.

- Besarnya sampel hendaknya jangan kurang dari 30.

Adapun pengambilan sampel dengan Sampel Jenuh, yaitu pengambilan sampel secara keseluruhan sebanyak 70 orang, sebagai data penelitian sebanyak 40 orang dan data uji coba sebanyak 30 orang. Untuk lebih jelasnya dapat terlihat pada tabel 3.1 berikut ini:

Tabel 3.1

Guru PNS di SMA Negeri 13 Palembang Tahun 2019

\begin{tabular}{|c|c|c|c|c|c|c|}
\hline \multirow{2}{*}{ Jenis Kelamin } & \multirow{2}{*}{ Jumlah Guru } & \multicolumn{2}{|c|}{ Tingkat Pendidikan } & \multirow{2}{*}{$\begin{array}{l}\text { Jumlah Guru } \\
\text { Sertifikasi }\end{array}$} & \multirow{2}{*}{$\begin{array}{c}\text { Jumlah } \\
\text { Sampel Data }\end{array}$} & \multirow{2}{*}{$\begin{array}{c}\text { Jumlah Sampel } \\
\text { Uji Coba }\end{array}$} \\
\hline & & S1 & S2 & & & \\
\hline Laki-laki & 15 & 9 & 6 & 13 & 10 & 7 \\
\hline Perempuan & 49 & 35 & 14 & 46 & 30 & 23 \\
\hline Jumlah & 64 & 44 & 20 & 59 & 40 & 30 \\
\hline
\end{tabular}

Sumber: SMA Negeri 13 Palembang, 2019

\section{HASIL PENELITIAN}

Sesuai dengan tujuan penelitian dalam bab ini dibahas secara berturut-turut tentang pengujian instrument (uji validitas dan reliabilitas), penyajian hasil penelitian bentuk deskripsi data dari masing - masing 55variabel, pengujian persyaratan analisis (Uji Normalitas, Uji Homogenitas, dan Uji Linieritas), Uji Asumsi Klasik (Heraskoresdisitas, Multikolenieritas), pengujian hipotesis Pengaruh Gaya Kepemimpinan, Budaya Organisasi dan Kompetensi terhadap Kinerja Guru di SMA Negeri 13 Palembang, baik secara parsial maupaun secara simultan, pembahasan hasil penelitian yang telah diolah dengan program SPSS (Statistical Program for Social Science) versi 17 for windows., serta mencoba memberikan kesimpulan dari hasil tersebut.

\section{Analisis Statistik Deskriptif}

Hasil pengolahan data tentang variable Gaya Kepemimpinan yang diperoleh melalui instrumen yang diberikan kepada 40 responden sebanyak 14 butir pertanyaan, ternyata hasilnya menunjukkan bahwa skor terendah 56, dan skor tertinggi 66. Data terkumpul setelah diolah maka menghasilkan rata-rata (mean) sebesar 61,00, median sebesar 60.77, modusnya sebesar 60 dan simpangan bakunya 2,970. Data tersebut menunjukkan bahwa rata-rata (mean) danmodus dengan median yang tidak jauh berbeda.

Untuk mengetahui diskripsi data variabel Budaya Organisasi Guru SMA Negeri 13 Palembang, peneliti berupaya mengumpulkan data tentang Budaya Organisasi Guru terhadap sejumlah 40 responden. Dari hasil pengolahan data tentang Budaya Organisasi Guru yang diperoleh melalui instrumen yang diberikan kepada responden sebanyak 18 butir pertanyaan, maka hasil penelitian menunjukkan bahwa skor terendah 83 dan skor tertinggi 90. Data yang terkumpul tersebut setelah diolah maka menghasilkan nilai rata-rata (mean) 76,40, median 76,36, modus 79 simpangan bakunya 3,018. Data tersebut menunjukkan bahwa rata-rata yang tidak terlalu jauh berbeda. Hal ini menggambarkan bahwa distribusi variabel Budaya Organisasi sebaran datanya cenderung berdistribusi normal.

Untuk mengetahui diskripsi data variabel Kompetensi Guru di SMA Negeri 13 Palembang, peneliti berupaya mengumpulkan data tentang Kompetensi Guru terhadap sejumlah 40 responden. Dari hasil pengolahan data tentang Kompetensi Guru yang diperoleh melalui instrumen yang diberikan kepada responden sebanyak 14 butir pertanyaan, maka hasil penelitian menunjukkan bahwa skor terendah 71 dan skor tertinggi 83. Data yang terkumpul tersebut setelah diolah maka menghasilkan nilai rata-rata (mean) 87,85 median 87,87 , modus 83 dan simpangan bakunya 2,420 . Data tersebut menunjukkan bahwa rata-rata yang tidak terlalu jauh berbeda. Hal ini menggambarkan bahwa distribusi variabel Disiplin Kerja sebaran datanya cenderung berdistribusi normal.

Dari data yang terkumpul setelah diolah tentang data Kinerja Guru di SMA Negeri 13 Palembang melalui instrumen yang diberikan kepada 40 responden, maka diperoleh skor terendah sebanyak 58 dan skor tertinggi sebanyak 68 , kemudian dari data yang terkumpul setelah diolah maka menghasilkan nilai rata-rata (mean) sebesar 62,33, median 62,64 modus 62 dan simpangan baku 2,503. Dari data tersebut menunjukkan bahwa rata-rata hitung (mean) dan modus dengan median yang tidak jauh berbeda. Hal ini menggambarkan bahwa distribusi frekuensi variabel Kinerja Guru di SMA Negeri 13 Palembang sebaran datanya cenderung berdistribusi normal. 
Tabel 4.1

Frekuensi Distribusi Variabel

\begin{tabular}{|c|c|c|c|c|c|}
\hline & & KINERJA GURU (Y) & $\begin{array}{l}\text { GAYA } \\
\text { KEPEMIMPINAN }\left(\mathrm{X}_{1}\right)\end{array}$ & $\begin{array}{l}\text { BUDAYA } \\
\text { ORGANISASI }\left(\mathrm{X}_{2}\right)\end{array}$ & KOMPETENSI $\left(\mathrm{X}_{3}\right)$ \\
\hline \multirow[t]{2}{*}{$\mathrm{N}$} & Valid & 40 & 40 & 40 & 40 \\
\hline & Missing & 0 & 0 & 0 & 0 \\
\hline \multicolumn{2}{|l|}{ Mean } & 62.33 & 61.00 & 76.40 & 87.85 \\
\hline \multicolumn{2}{|c|}{ Std. Error of Mean } & .347 & .412 & .419 & .336 \\
\hline \multicolumn{2}{|c|}{ Median } & $62.64^{\mathrm{a}}$ & $60.77^{\mathrm{a}}$ & $76.36^{a}$ & $87.87^{\mathrm{a}}$ \\
\hline \multicolumn{2}{|l|}{ Mode } & 62 & $60^{\mathrm{b}}$ & 79 & 90 \\
\hline \multicolumn{2}{|c|}{ Std. Deviation } & 2.503 & 2.970 & 3.018 & 2.420 \\
\hline \multicolumn{2}{|c|}{ Variance } & 6.264 & 8.824 & 9.108 & 5.858 \\
\hline \multicolumn{2}{|l|}{ Range } & 10 & 10 & 12 & 9 \\
\hline \multicolumn{2}{|l|}{ Minimum } & 58 & 56 & 71 & 83 \\
\hline \multicolumn{2}{|l|}{ Maximum } & 68 & 66 & 83 & 92 \\
\hline \multicolumn{2}{|l|}{ Sum } & 3241 & 3172 & 3973 & 4568 \\
\hline \multirow[t]{11}{*}{ Percentiles } & 10 & $58.40^{c}$ & $56.71^{c}$ & $72.28^{c}$ & $84.28^{c}$ \\
\hline & 20 & 59.63 & 58.11 & 73.57 & 85.76 \\
\hline & 25 & 61.08 & 58.86 & 74.00 & 86.19 \\
\hline & 30 & 61.48 & 59.28 & 74.43 & 86.51 \\
\hline & 40 & 62.16 & 59.97 & 75.36 & 87.17 \\
\hline & 50 & 62.64 & 60.77 & 76.36 & 87.87 \\
\hline & 60 & 63.13 & 62.20 & 77.57 & 88.84 \\
\hline & 70 & 63.67 & 63.07 & 78.40 & 89.40 \\
\hline & 75 & 63.95 & 63.50 & 78.87 & 89.82 \\
\hline & 80 & 64.30 & 63.93 & 79.23 & 90.15 \\
\hline & 90 & 65.10 & 65.07 & 79.97 & 90.84 \\
\hline
\end{tabular}

Sumber : Hasil Pengolahan Data

\section{Uji Validitas}

Berdasarkan hasil 56 bsolute Correlation Pearson Moment dengan menggunakan program SPSS menyatakan bahwa seluruh butir pertanyaan baik untuk variabel Kinerja Guru $(\mathrm{Y})$, Gaya Kepemimpinan $\left(\mathrm{X}_{1}\right)$, Budaya Organisasi $\left(\mathrm{X}_{2}\right)$ dan Kompetensi $\left(\mathrm{X}_{3}\right)$ adalah valid. Hal ini ditunjukkan dengan melihat nilai Sig. (2-tailed) lebih kecil atau sama dengan 0,05 pada tabel.

Berdasarkan hasil uji instrument sebanyak 14 butir pernyataan 56 bsolute Gaya Kepemimpinan, didapatkan hasil seluruh pernyataan memiliki total score pearson correlation $(r)>0,3061$, maka dapat disimpulkan bahwa seluruh item dinyatakan valid. Berdasarkan hasil uji instrument sebanyak 18 butir pernyataan 56 bsolute Budaya Organisasi, didapatkan hasil seluruh pernyataan memiliki total score pearson correlation $(r)>0,3061$, maka dapat disimpulkan bahwa seluruh item dinyatakan valid. Berdasarkan hasil uji instrument sebanyak 14 butir pernyataan 56 bsolute Kompetensi, didapatkan hasil seluruh pernyataan memiliki total score pearson correlation $(r)>0,3061$, maka dapat disimpulkan bahwa seluruh item dinyatakan valid. Berdasarkan hasil uji instrument sebanyak 18 butir pernyataan 56 bsolute Kinerja Guru, didapatkan hasil seluruh pernyataan memiliki total score pearson correlation $(r)>0,3061$, maka dapat disimpulkan bahwa seluruh item dinyatakan valid.

\section{Uji Reliabilitas}

Uji reliabilitas adalah pengujian untuk membuktikan bahwa 56bsolute56t yang digunakan konstans atau tidak berubah. Uji Reliabilitas yang digunakan dalam penelitian adalah dengan menggunakan teknik Cronbach's Alpa melalui program SPSS versi 17.0. Hasil pengujian reliabilitas masing-masing 56 bsolute dapat dilihat pada tabel dibawah ini. Berdasarkan tabel dibawah ini terlihat bahwa nilai Alpha Cronbach hitung lebih besar dari syarat 56bsolut $\alpha$ (alpha) yaitu 0,60 . Hal ini menunjukkan bahwa masing-masing variabel dalam penelitian ini memiliki tingkat reliabilitas yang tinggi.

Tabel 4.2

Hasil Analisis Uji Reliabilitas

\begin{tabular}{lllll}
\hline Item-Total Statistics & & & \\
\hline & Scale Mean if Item Scale & Variance & if Corrected Item-Total Cronbach's & Alpha \\
& Deleted & if & Item Deleted \\
\hline KINERJA GURU $(\mathrm{Y})$ & 225.25 & 45.015 & .878 & .707 \\
\hline GAYA KEPEMIMPINAN $\left(\mathrm{X}_{1}\right)$ & 226.58 & 54.837 & .389 & .919 \\
\hline BUDAYA ORGANISASI $\left(\mathrm{X}_{2}\right)$ & 211.17 & 42.969 & .725 & .769 \\
\hline KOMPETENSI $\left(\mathrm{X}_{3}\right)$ & 199.73 & 48.750 & .774 & .756 \\
\hline
\end{tabular}




\section{Analisis Statistik Inferensial}

\section{a. Uji Prasyarat}

\section{- Uji Normalitas}

Uji normalitas dimaksudkan untuk melihat layak atau tidaknya data hasil penelitian. Dalam 57bsolute statistik parametrik, asumsi yang digunakan adalah hasil data dari setiap variabel yang diteliti berdistribusi normal. Dengan asumsi tersebut, maka dalam setiap penelitian yang menggunakan rancangan statistik parametrik distribusi data variabel harus diuji terlebih dahulu apakah data tersebut berdistribusi normal atau tidak. Jika setelah dilakukan uji mormalitas terhadap data ternyata berdistribusi normal, maka penelitian dapat dilanjutkan dan sebaliknya. Uji normalitas data dalam penelitian ini dilakukan dengan menggunakan program SPSS. Suatu data dikatakan berdistribusi normal apabila nilai asymp. Sig. (2tailed) > (lebih besar) dari tingkat alpha yang ditetapkan yaitu $5 \%(0,05)$. Hasil 57 bsolute uji normalitas disajikan dalam tabel 4.3 berikut ini:

Tabel 4.3

Hasil Analisis Uji Normalitas

\begin{tabular}{|c|c|c|c|c|c|}
\hline \multicolumn{6}{|c|}{ One-Sample Kolmogorov-Smirnov Test } \\
\hline & & $\begin{array}{l}\text { KINERJA } \\
(\mathrm{Y})\end{array}$ & $\begin{array}{l}\text { GURU GAYA } \\
\text { KEPEMIMPINAN }\left(\mathrm{X}_{1}\right)\end{array}$ & $\begin{array}{l}\text { BUDAYA } \\
\text { ORGANISASI }\left(\mathrm{X}_{2}\right)\end{array}$ & KOMPETENSI $\left(\mathrm{X}_{3}\right)$ \\
\hline $\mathrm{N}$ & & 40 & 40 & 40 & 40 \\
\hline \multirow[t]{2}{*}{ Normal Parameters $\mathrm{s}^{\mathrm{a}, \mathrm{b}}$} & Mean & 62.33 & 61.00 & 76.40 & 87.85 \\
\hline & Std. Deviation & 2.503 & 2.970 & 3.018 & 2.420 \\
\hline \multirow[t]{3}{*}{ Most Extreme Differences } & Absolute & .198 & .153 & .151 & .159 \\
\hline & Positive & .120 & .132 & .133 & .098 \\
\hline & Negative & -.198 & -.153 & -.151 & -.159 \\
\hline Kolmogorov-Smirnov Z & & 1.428 & 1.107 & 1.091 & 1.149 \\
\hline Asymp. Sig. (2-tailed) & & .134 & .173 & .185 & .142 \\
\hline
\end{tabular}

Berdasarkan tabel diatas terlihat bahwa nilai Asymp. Sig. (2-tailed) untuk ketiga variabel lebih besar dari nilai alpha yang ditetapkan yaitu 0,05 maka data variabel dalam penelitian ini adalah berdistribusi normal. Hal itu juga terlihat dari nilai Kolmogorov-Smirnov $Z$ yang menunjukkan angka positif.

\section{Uji Homogenitas}

Uji Homogenitas dimaksudkan untuk menguji kesamaan dua buah varians populasi yang berdistribusi normal sehingga diketahui apakah data sampel diperoleh dari populasi yang bervarians homogeny atau tidak. Hasil analisis uji homogenitas dapat dilihat bahwa semua variabel homogenitas.

\section{Uji Linearitas}

Uji linearitas dimaksudkan untuk mengetahui apakah terjadi penyimpangan linearitas atau tidak. Sebelum dilakukan 57 bsolute regresi linear, terlebih dahulu dilakukan pengujian linearitas dengan tujuan untuk mengetahui apakah terjadi penyimpangan linearitas atau tidak.

Berdasarkan hasil pengolahan data diketahui nilai Sig. Pada baris Deviation from Linearity diperoleh nilai sebesar
$0,91,0,77$, dan 0,15 , atau lebih besar dari alpha $5 \%(0,05)$ maka Ho diterima artinya variabel $X_{1}, X_{2}$ dan $X_{3}$ mempunyai hubungan yang linear dengan variabel $Y$. Berdasarkan uji inferensial di atas menunjukkan bahwa semua persyaratan masing-masing variabel telah terpenuhi sehingga 57 bsolute statistik model dalam penelitian ini dapat dilakukan.

\section{Uji Asumsi Klasik}

\section{Uji Multikolinearitas}

Berikut ini hasil dari uji multikolinearitas antara 57 bsolute- 57 bsolute bebas yaitu Gaya Kepemimpinan, Budaya Organisasi dan Kompetensi.

Berdasarkan hasil pengolahan data tersebut di atas, untuk menguji ada atau tidaknya mulkolinearitas pada model regresi linier dapat dilakukan dengan melihat nilai VIF masing-masing 57 bsolute independen dan melihat nilai korelasi antar 57 bsolute independen. Menurut Santoso (2010) uji asumsi mulikolinieritas ini dilakukan dengan cara menghitung nilai Variance Inflating Factor (VIF), apabila VIF lebih kecil dari 5 maka berarti tidak terjadi multikolinieritas.

\section{Tabel 4.4}

Hasil Uji Multikolinearitas Variabel Bebas

\begin{tabular}{|c|c|c|}
\hline \multirow[t]{2}{*}{ - $\quad$ Model } & \multicolumn{2}{|c|}{ Collinearity Statistics } \\
\hline & Tolerance & VIF \\
\hline \multicolumn{3}{|l|}{ - $\quad$ (Constant) } \\
\hline GAYA KEPEMIMPINAN & .807 & 1.240 \\
\hline BUDAYA ORGANISASI & .941 & 1.063 \\
\hline KOMPETENSI & .836 & 1.196 \\
\hline
\end{tabular}


Pada table di atas, diketahui bahwa nilai VIF dari masing- masing 58 bsolute independen lebih kecil dari pada 5, yaitu nilai VIF Absolute Gaya Kepemimpinan sebesar 1,240, nilai VIF 58 bsolute Budaya Organisasi sebesar 1,063 dan nilai VIF 58bsolute Kompetensi sebesar 1,196. Dengan demikian dapat disimpulkan bahwa di antara 58bsolute independen tersebut tidak ada korelasi atau tidak terjadi multikolinearitas pada model regresi linier.

\section{Tabel 4.5}

Hasil Uji Heteroskedastisitas

\section{Uji Heteroskedastisitas}

Pada penelitian ini gejala heteroskedastisitas dideteksi dengan metode Glejser: Dasar pengambilan Uji Heteroskedastisitas adalah Jika nilai signifikansi (sig) antara variable independen dengan 58 bsolute residual lebih besar dari 0,05, maka tidak terjadi masalah heteroskedastisitas.

\begin{tabular}{|c|c|c|c|c|c|c|}
\hline \multicolumn{7}{|c|}{ Coefficients $^{\mathrm{a}}$} \\
\hline & \multirow{2}{*}{ Model } & \multicolumn{2}{|c|}{ Unstandardized Coefficients } & \multirow{2}{*}{$\frac{\text { Standardized Coefficients }}{\text { Beta }}$} & \multirow[t]{2}{*}{$t$} & \multirow[t]{2}{*}{ Sig. } \\
\hline & & B & Std. Error & & & \\
\hline \multirow[t]{4}{*}{1} & (Constant) & 10.049 & 5.517 & & 1.822 & .079 \\
\hline & GAYA KEPEMIMPINAN & -.033 & .050 & -.125 & -.654 & .518 \\
\hline & BUDAYA ORGANISASI & -.026 & .130 & -.035 & -.199 & .843 \\
\hline & KOMPETENSI & -.089 & .045 & -.373 & -1.989 & .056 \\
\hline
\end{tabular}

a. Dependent Variable: Kinerja

Dari tabel hasil perhitungan diatas dapat dijelaskan bahwa seluruh variable independent tidak terjadi masalah heteroskedastisitas, hal ini terlihat pada nilai signifikansi masing-masing variable melebihi atau lebih besar dari 0,05 dengan nilai Gaya Kepemimpinan 0,518, Budaya Organisasi 0,843, dan Kompetensi 0,056.

Dari hasil uji asumsi klasik maka variable Gaya Kepemimpinan, Budaya Organisasi dan Kompetensi bebas dari multikolinearitas dan heteroskedastisitas sehingga dapat digunakan dalam analisis regresi linier berganda.

\section{b. Model Regresi}

\section{Analisis Regresi Linear Berganda}

Analisis Regresi linear berganda digunakan untuk mengetahui besarnya pengaruh antara variabel Gaya Kepemimpinan $\left(\mathrm{X}_{1}\right)$, Budaya Organisasi $\left(\mathrm{X}_{2}\right)$ dan variabel Kompetensi $\left(\mathrm{X}_{3}\right)$ terhadap Kinerja Guru $(\mathrm{Y})$. Hasil analisis statistika dengan bantuan SPSS diperoleh koefisien regresi seperti pada tabel dibawah ini.

Tabel 4.6

Hasil Analisis Regresi Linear Berganda

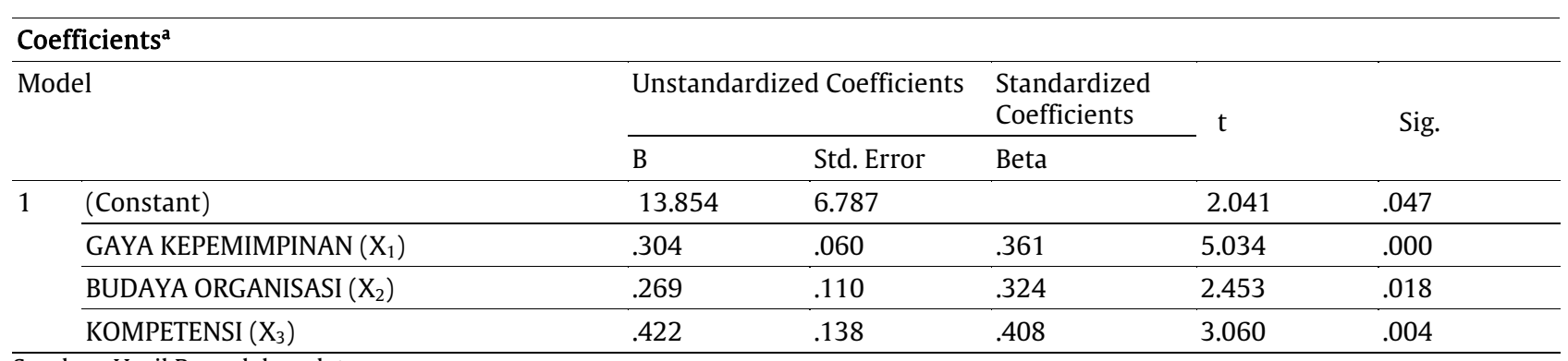

Sumber: Hasil Pengolahan data.

\section{- Persamaan Regresi Linear Berganda:}

$$
\hat{Y}=13,854+0,304 X_{1}+0,269 X_{2}+0,422 X_{3}+e
$$

- Koefisien Regresi (b) :

- $\quad b_{0}=13,854$ artinya: jika tidak ada peningkatan Gaya Kepemimpinan, Budaya Organisasi dan Kompetnsi maka Kinerja Guru sebesar 13,854.

- $b_{1}=0,304$ artinya: jika ada Gaya Kepemimpinan meningkat maka Kinerja Guru akan meningkat sebesar 0,304 dengan asumsi bahwa faktor lain tetap.

- $b_{2}=0,269$ artinya: jika ada Budaya Organisasi meningkat maka Kinerja Guru akan meningkat sebesar 0,269 dengan asumsi bahwa faktor lain tetap.

- $b_{3}=0,422$ artinya: jika ada Kompetensi meningkat maka Kinerja Guru akan meningkat sebesar 0,422 dengan asumsi bahwa faktor lain tetap.

\section{- Koefisien Korelasi}

Berdasarkan hasil uji analisi korelasi didapatkan nilai sig > 0,5 dengan mempunyai tanda positif. Dengan uraian sebagai berikut:

- Variabel $X_{1}$ (Gaya Kepemimpinan) terhadap Y (Kinerja Guru) memiliki korelasi yang substansial, karena nilai sig $=0,562$ sebagaimana pengelempokan sig 0,40 - 0,69 bernilai sedang.

- Variabel $X_{2}$ (Budaya Organisasi) terhadap Y (Kinerja Guru) memiliki korelasi yang sangat tinggi karena nilai $\operatorname{sig}=0,766$ sebagaimana pengelempokkan sig 0,70 - 1 bernilai sangat tinggi.

- Variabel $X_{3}$ (Kompetensi) terhadap Y (Kinerja Guru) memiliki korelasi yang sangat tinggi karena nilai sig $=0,789$ sebagaimana pengelempokkan sig 0,70 - 1 bernilai sangat tinggi.

\section{- Koefisien Determinasi}


Koefisien determinasi $\left(\mathrm{R}^{2}\right)$ digunakan untuk mengukur secara bersama-sama (agregat) seberapa besar pengaruh semua variabel independen terhadap variabel dependen. Dalam penelitian ini koefisien determinasi $\left(R^{2}\right)$ digunakan untuk mengukur pengaruh Gaya Kepemimpinan $\left(\mathrm{X}_{1}\right)$, Budaya Organisasi $\left(\mathrm{X}_{2}\right)$ dan Kompetensi $\left(\mathrm{X}_{3}\right)$ secara bersama-sama (agregat) terhadap Kinerja Guru (Y).

Hasil analisis statistika dengan bantuan SPSS relase 17,0 diperoleh koefisien determinasi $\left(R^{2}\right)=0,757$ yang artinya sebesar 75 \% variabel Kinerja Guru (Y) dapat dijelaskan oleh variabel Gaya Kepemimpinan $\left(\mathrm{X}_{1}\right)$, Budaya Organisasi $\left(X_{2}\right)$ dan Kompetensi ( $X_{3}$, sedangkan $25 \%$ dijelaskan oleh faktor lain yang tidak tercakup dalam persamaan regresi.

\section{- Analisis Regresi Linear Sederhana}

\section{- Pengaruh Gaya Kepemimpinan terhadap Kinerja Guru.}

Analisis Regresi linear sederhana digunakan untuk mengetahui besarnya pengaruh antara variabel Gaya Kepemimpinan $\left(\mathrm{X}_{1}\right)$ terhadap Kinerja Guru (Y).

\section{- Persamaan regresi linear sederhana:}

$$
\hat{Y}=43.069+0,581 X_{1}+e
$$

- Koefisien regresi (b):

- $\quad b_{0}=43,069$ artinya: jika tidak ada peningkatan Gaya Kepemimpinan maka Kinerja Guru 43,069.

- $\mathrm{b}_{1}=0,581$ artinya: jika ada Gaya Kepemimpinan meningkat maka Kinerja Guru akan meningkat sebesar 0,581 dengan asumsi bahwa faktor lain tetap.

\section{- Koefisien Determinasi}

Hasil analisis statistika diperoleh koefisien determinasi $\left(R^{2}\right)=0,148$ yang artinya sebesar $14 \%$ variabel Kinerja Guru (Y) dapat dijelaskan oleh variabel Gaya Kepemimpinan $\left(\mathrm{X}_{1}\right)$, sedangkan 86 \% dijelaskan oleh faktor lain yang tidak tercakup dalam persamaan regresi.

\section{- Pengaruh Budaya Organisasi terhadap Kinerja Guru.}

\section{- Persamaan regresi linear sederhana:}

$\hat{\mathrm{Y}}=35,263+0,672 \mathrm{X}_{2}+\mathrm{e}$

- Koefisien regresi (b):

$\mathrm{b}_{0}=35,263$ artinya: jika tidak ada peningkatan Budaya Organisasi maka Kinerja Guru 35,263.

- $\mathrm{b}_{2}=0,672$ artinya : jika ada Budaya Organisasi meningkat maka Kinerja Guru akan meningkat sebesar 0,672 dengan asumsi bahwa faktor lain tetap.

\section{- Koefisien Determinasi}

Hasil analisis statistika diperoleh koefisien determinasi $\left(R^{2}\right)=0,69$.

\section{- Pengaruh Kompetensi terhadap Kinerja Guru .}

- Persamaan regresi linear sederhana:

\section{- Koefisien regresi (b):}

- $b_{0}=42,596$ artinya: jika tidak ada peningkatan Kompetensi maka Kinerja Guru 42,596.

- $\quad b_{3}=0,573$ artinya : jika ada Kompetensi meningkat maka Kinerja Guru akan meningkat sebesar 0,573 dengan asumsi bahwa faktor lain tetap.

\section{- Koefisien Determinasi}

Hasil analisis statistika diperoleh koefisien determinasi $\left(R^{2}\right)=0,58$.

\section{- Analisis Variasi (ANOVA)}

Analisis variasi (ANOVA) berfungsi seberapa besar pengaruh variasi dari variabel independen terhadap variabel dependen. Dalam penelitian ini akan dianalisis seberapa besar pengaruh variasi Gaya Kepemimpinan $\left(\mathrm{X}_{1}\right)$, Budaya Organisasi $\left(\mathrm{X}_{2}\right)$ dan Kompetennsi $\left(\mathrm{X}_{3}\right)$ secara bersama-sama terhadap Kinerja Guru (Y). Uji yang digunakan dalam analisis variasi adalah Uji-F. Hasil analisis statistika dengan menggunakan aplikasi SPSS ver 17 diperoleh analisis variasi (ANOVA) $\mathrm{R}^{2}=0,69$ artinya sebesar 69\% variabel Kinerja Guru (Y) dapat dijelaskan oleh variabel Budaya Organisasi $\left(\mathrm{X}_{2}\right)$, sedangkan 31\% dijelaskan oleh faktor lain yang tidak tercakup dalam persamaan regresi.

Hasil analisis statistika dengan menggunakan Uji-F (ANOVA), bahwa Gaya Kepemimpinan $\left(X_{1}\right)$, Budaya Organisasi $\left(\mathrm{X}_{2}\right)$ dan Kompetensi $\left(\mathrm{X}_{3}\right)$ secara bersama-sama signifikan terhadap Kinerja Guru (Y). Keadaan ini ditunjukkan oleh nilai $\mathrm{F}_{\text {hitung }}=28,733>\mathrm{F}_{3.221}(\mathrm{sig}=0,000<$ $0,05)$.

Bentuk pengaruh antara Gaya Kepemimpinan, Budaya Organisasi dan Kompetensi terhadap Kinerja Guru melalui persamaan $\hat{Y}=13,854+0,304 X_{1}+0,269 X_{2}+0,422 X_{3}+e$.

\section{KESIMPULAN}

1. Model regresi linier berganda untuk melihat pengaruh gaya kepemimpi nan budaya organisasi dan kompetensi terhadap kinerja guru adalah

$$
\hat{Y}=13,854+0,304 X_{1}+0,269 X_{2}+0,422 X_{3}+e
$$

2. Dari hasil persamaan model regresi tersebut dihasilkan nilai rata-rata kinerja guru sebesar 13,854 satuan dengan asumsi faktor lainnya dianggap tetap.

- Untuk variabel gaya kepemimpinan diperoleh koefisien regresi positif $(0,304)$, yang berarti semakin baik kepemimpinan diterapkan akan semakin baik pula kinerja guru.

- Dari variabel budaya organisasi juga diperoleh koefisien regresi positif $(0,269)$, yang berarti semakin kondusif budaya organisasi maka akan semakin baik pula kinerja guru.

- Dari variabel kompetensi juga diperoleh koefisien regresi positif $(0,422)$, yang berarti semakin profesional kompetensi guru maka akan semakin baik pula kinerja guru.

- Hasil analisis regresi secara simultan diperoleh nilai F hitung $(28,733)>$ dari $\mathrm{F}$ tabel $(3,221)$ atau $p$ value $(0,00)$ lebih kecil dari taraf nyata $5 \%$ yang berarti bahwa antara variabel gaya kepemimpinan, budaya 
organisasi dan kompetensi dapat dinyatakan secara bersama-sama $\left(\mathrm{X}_{1}, \mathrm{X}_{2}\right.$ dan $\left.\mathrm{X}_{3}\right)$ mempunyai pengaruh terhadap kinerja guru $(\mathrm{Y})$.

- Nilai R = 0,626 (63,0\%) menunjukkan besarnya nilai korelasi variabel bebas dengan variabel terikat.

- $\quad$ Nilai koefisien determinasi (R square) $=0,757(76 \%)$ yang merupakan kontribusi rata-rata pengaruh $\mathrm{X}_{1}$, $\mathrm{X}_{2}$ dan $\mathrm{X}_{3}$ terhadap $\mathrm{Y}$, sedangkan $24 \%$ dipengaruhi oleh faktor lain. Ini berarti bahwa pengaruh gaya kepemimpinan, budaya organisasi dan kompetensi cukup besar terhadap kinerja guru di SMA Negeri 13 Palembang.

\section{SARAN}

Berdasarkan hasil penelitian yang telah disimpulkan diatas, maka perlu diberikan saran kepada pihak terkait pada penelitian ini.

- Bagi para guru di SMA Negeri 13 Palembang, agar dapat mempertahan kan bahkan meningkatkan kinerja yang sudah terlaksana dengan baik selama ini dalam rangka meningkat kan performance sekolah.

- Bagi Kepala Sekolah SMA Negeri 13 Palembang beserta perangkatnya agar senantiasa menjaga kondisi rasa kekeluargaan yang akan menciptakan suasana kerja yang nyaman dalam mendukung aktifitas guru.

- Pimpinan Sekolah hendaknya terus mengembangkan gaya kepemimpi nan dan budaya organisasi yang positif sesuai dengan situasi dan kondisi yang ada di sekolah agar kinerja guru menjadi lebih baik dalam meningkatkan motivasi dan profesional guru.

- Bagi guru yang sudah memiliki kompetensi untuk terus meningkatkan, mengembangkan ilmu dan keterampilan secara profesional dalam mengemban tugas dan amanat mencerdaskan kehidupan bangsa.

\section{Implikasi}

Berdasarkan uraian kesimpulan di atas diketahui bahwa ke empat hipotesis penelitian yang diajukan diterima yaitu variabel gaya kepemimpinan, budaya organisasi dan kompetensi secara bersama-sama mempunyai pengaruh yang erat dan positif (searah) dengan kinerja guru. Variabel gaya kepemimpinan terdapat pengaruh secara nyata dengan kinerja guru, variabel budaya organisasi terdapat pengaruh secara nyata dengan kinerja guru, serta variabel kompetensi terdapat pengaruh secara nyata dengan kinerja guru di SMA Negeri 13 Palembang.

Hal ini menunjukkan bahwa upaya untuk meningkatkan kinerja guru SMA Negeri 13 Palembang dapat dilakukan melalui upaya peningkatan gaya kepemimpinan kepala sekolah yang seharusnya lebih memperhatikan, mengarahkan para guru untuk lebih menciptakan budaya organisasi yang baik serta mendukung profesionalisme melalui kompetensi guru yang lebih baik dalam menjalankan tugas dan tanggungjawab sebagai pendidik.

Upaya peningkatan gaya kepemimpinan, budaya organisasi dan kompetensi pada gilirannya akan meningkatkan kinerja guru, yaitu melalui upaya internalisasi dan sosialisasi kepada guru, sehingga jika gaya kepemimpinan, budaya organisasi dan kompetensi yang diterapkan efektif dan meningkat maka niscaya kinerja guru juga akan meningkat.

\section{DAFTAR PUSTAKA}

Arikunto, Suharsimi, 2012; Prosedur Penelitian Mutu Pendidikan Berbasis Sekolah; Manajemen Peningkatan Mutu Pendidikan Sekolh Dasar Dari Sentralisasi menuju Desentralisasi, Jakarta: Bumi Aksara.

Handoko. T, Hani, 2007, Manajemen Sumber Daya Manusia, edisi VIII. Jogjakarta: BP. F. Ekonomi

Hasibuan, 2010; Dasar-Dasar Manajemen dan Administrasi. Jakarta: Graha Indinesia.

Mangkunegara. Anwar A. A, 2010; Manajemen Sumber Daya Manusia Perusahaan, Bandung: Rosdakarya.

Mulyasa, 2005; Manajemen Berbasis Sekolah. Jakarta: Depdiknas.

Ndraha, Taliziduhu. 2005. Budaya Organisasi, Jakarta, Rineke Cipta.

Ndraha, Taliziduhu. 2014. Pengantar Teori Pengembangan Sumberdaya Manusia, Jakarta, Rineka Cipta.

Schan, Edgar H, 1999: Organizational Culture and Leadership, Sanfrancisco, Josseybass.

Simamora. Hendry,2010; Manajemen Sumber Daya Manusia, Yogyakaarta, STIE-YKPN.

Sugiono, 2010; Metode Penelitian Bisnis, Bandung, CV. Alfabeta.

Undang-Undang RI Nomor 20 Tahun 2003, Tentang Sistem Pendidikan Nasional, Bandung, Citra Umbara.

Undang-Undang RI Nomor 14 Tahun 2015, Tentang Guru dan Dosen, Bandung, Citra Umbara.

Undang-Undang RI Nomor 19 Tahun 2015, Tentang Standar Nasional Pendidikan, Jakarta, Depdiknas.

Peraturan Menteri Pendidikan Nasional RI Nomor 18 Tahun 2007 Tentang Sertifikasi Bagi Guru Dalam Jabatan, Jakarta, Bumi Aksara.

http://jurnal pendidikan manajemen perkantoran.vol.1, nomor 1-Agustus 2016 kompetensi dan kinerja guru berdasarkan sertifikasi profesi-oleh kowara, rasto, diakses tanggal 5 Agustus 2019.

http://www.ejournal.pelitaindonesia.ac.id/ojs32/index.php/pro curatio/article/view/91/ procuratio : jurnal ilmiah manajemen-pengaruh gaya kepemimpinan organisasi serta motivasi kerja terhadap kepuasan kerja dan kinerja guru sekolah dasar di kecamatan rimba melintang-oleh kuswoyo; komara, asmara hendra; junaedi, achmad tavip, diakses tanggal 5 Agustus 2019. 